Directory of Directories on the Internet: A Guide to Information Resources, by Gregory B. Newby ( 153 pages, December 1993), offers a comprehensive overview of the Internet and the relations among different information resources. The first chapter describes "tools that are so easy to use that you can navigate the network for hours (and still not necessarily find what you were looking for)," while other chapters cover OPACs, e-mail, newsgroups, resources that are "useful for almost everyone," ftp directories, special interest areas, and books about the Internet. A copy is $\$ 29.95$ from the Meckler Corp., 11 Ferry Lane West, Westport, CT 06880. ISBN 0-88736-768-2.

On Internet '94, edited by Tony Abloott (453 pages, December 1993), is an international guide to resources on the Internet that goes far beyond the introductory nature of Newby's directory. Capsule descriptions of hundreds of discussion lists, mailing lists, electronic journals and newsletters, text archives, freenets and other community-based information resources, campuswide information systems, commercial services, USENET news-groups, and WAIS-accessible databases are provided. A subject index helps locate specific interests. Copies are $\$ 45.00$ from Meckler Publishing, 11 Ferry Lane West, Westport, CT 06880. ISBN 0-88736-929-4.

Downsizing Defense, edited by Ethan B. Kapstein (236 pages, November 1993), brings together analysts from government, industry, and academia to brainstorm on the policy changes needed to cope with U.S. defense cutbacks. Contributors conclude that converting guns to butter will be a long, painful process if economic growth continues to lag. It also provides a comparative perspective on the issues by examining how Europeans and Russians are dealing with lower levels of defense spending. Copies are available for $\$ 34.95$ from Congressional Quarterly Books, 1414 22nd St., N.W., Washington, DC 20037. ISBN 0-87187-945-X.

Guidelines for Library Support of Distance Learning in Canada has been pub- lished as Occasional Paper No. 8 of the Canadian Association of College and University Libraries' Library Services for Distance Learning Interest Group. Also recently published is Occasional $\mathrm{Pa}$ per No. 7, Fee-Based Services in Canadian Academic Libraries: A Survey, by Ian Gordon. Copies of each may be obtained for $\$ 10.00$ (nonmembers of CACUL) from the Canadian Library Association, 200 Elgin St., Suite 602, Ottawa, Ontario, Canada K2P 1 L5.

\section{An Introduction to Computer-Based} Library Systems, by Lucy A. Tedd (316 pages, 3d ed., 1993), reflects significant developments in information systems since the previous edition was published in 1984. The book includes many case studies (National Library of Portugal, University of Wales, and others) to illustrate particular system features. It will primarily be helpful for anyone interested in a global perspective and as a supplementary text to library or information studies. A copy may is \$59.95 from John Wiley \& Sons, 605 Third Ave., New York, NY 10158. ISBN 0-471-93787-8.

\section{Library Buildings Consultants List 1993,} edited by Kazuko Dailey and James Estrada (103 pages, 1993), provides a convenient starting point for librarians, administrators, and architects who need to employ buildings consultants. The individuals who appear in the list are self-selected; in other words, they responded to a public invitation to apply. But all have had experience on at least five library building projects within the past ten years. Appendices provide access by state, zip code, type of library, general experience, interior design experience, and specialized experience. Copies are $\$ 12.50$ (LAMA members, $\$ 10.00$ ) from the ALA Order Department, 50 E. Huron St., Chicago, IL 60611. ISBN 0-8389-7670-0.

\section{The Photographic Experience, 1839-1914:} Images and Attitudes, by Heinz K. Henisch and Bridget A. Henisch (462 pages, February 1994), examines reactions to the new photographic art by professionals, amateurs, and the 
general public in the years before World War I. The Henisches explore the varied relationships between photography and painting, book publishing, journalism, war, travel, humor, and the various ways the medium has expressed public and private sentiments. Lavishly illustrated with daguerreotypes, albumen prints, studio advertisements, stereo cards, and overpainted prints, this volume pays tribute to the photographic pioneers and the effect their images had on society. Copies are available for $\$ 95.00$ from Penn State Press, Suite C, Barbara Building, 820 N. University Dr., University Park, PA 16802. ISBN 0-271-00930-6.

\section{Projections of War: Hollywood, American}

\section{Culture, and World War II, by Thomas}

Doherty (364 pages, February 1994), reveals how and why Hollywood marshaled its artistic resources on behalf of the war and interprets the cultural meanings and enduring legacies of the motion picture record of the war years. Besides the wellknown combat features, Doherty examines comedies, musicals, newsreels, documentaries, cartoons, and army training films to show that Hollywood's effort was not merely vapid propaganda, but a collaborative effort to inform and educate as well as entertain. The Hollywood production code, the portrayal of women and blacks in films, and the wartime films' legacy in postwar and Vietnam-era films is also explored. The cost is $\$ 32.50$

from Columbia University Press, $562 \mathrm{~W}$. 113th St., New York, NY 10025. ISBN 0-231-08244-4.

Rainforests of the World, by Kathlyn Gay (219 pages, November 1993), is one of ABCClio's excellent monographs on contemporary world issues. Combining a summary of policy and scientific issues, biographies, a chronology of key events, statistics, a directory of organizations, primary documents, a bibliography and glossary, the book is an outstanding first choice for term papers or topical research.
A copy may be ordered for $\$ 39.50$ from $\mathrm{ABC}$ Clio, 130 Cremona Dr., Santa Barbara, CA 93117. ISBN 0-87436-712-3. Other volumes in this series cover global warming, sexual harassment, drug abuse, energy and American society, marine pollution, and capital punishment.

\section{Years: Special Collections at Kent} State University, edited by Dean H. Keller and Alex Glidzen (99 pages, January 1994), commemorates the first 25 years of Kent State's Department of Special Collections and Archives with a history of the department and a catalog of its Silver Anniversary Exhibition. The holdings range from German incunabula and McGuffey readers to early detective fiction and Bill Clinton's signature. A copy of the exhibition catalog may be ordered for $\$ 14.00$ from Kent State University Press, P.O. Box 5190, Kent, OH 44242-0001. ISBN 0-87338-500-4.

Western European Longuage Imprints from 18th-Century Russia ( 200 $35 \mathrm{~mm}$ microfilm reels) consists of some 3,500 titles published in German, French, Latin, English, and other European languages. The material represents Russia's active participation in the international scientific and cultural world of the 18th century, and documents the cultural, social, scientific, technical, and administrative life in Russia and its constituent nations. The Library of the Russian Academy of Sciences and the Russian National Library (formerly the Saltykov-Shchedrin Public Library) are primary sources for this microfilm collection. Other Russian libraries, together with those from the Baltic republics and elsewhere in the former Russian Empire, will join in the project. The collection will be released in 10 units of 20 reels each, beginning in April 1994. The cost is $\$ 4,800$ for standing orders of 4 units per year $(\$ 1,200$ per unit), or $\$ 1,400$ per individual unit. For more information, contact Norman Ross Publishing, Inc., 330 W. 58th St., Suite 214, New York, NY 10019; (800) 648-8850. 